\title{
Fatty acid composition of the Caprellidea (Crustacea: Amphipoda) from the Strait of Gibraltar*
}

\author{
JOSÉ MANUEL GUERRA-GARCÍA ${ }^{1}$, INÉS MARTÍNEZ-PITA ${ }^{1}$ and MARÍA LUISA PITA² \\ ${ }^{1}$ Laboratorio de Biología Marina, Departamento de Fisiología y Zoología, Facultad de Biología, Universidad de Sevilla, \\ Avda Reina Mercedes 6, 41012 Sevillla, Spain. E-mail: jmguerra@us.es \\ ${ }^{2}$ Departamento de Bioquímica Médica y Biología Molecular, Facultad de Medicina, Universidad de Sevilla, \\ Avda. Sánchez-Pizjuán 4, 41009 Sevilla, Spain.
}

\begin{abstract}
SUMMARY: The total fatty acid composition of nine species of caprellidean amphipods collected from the Strait of Gibraltar was investigated. All caprellids were characterised by high levels of polyunsaturated fatty acids, mainly eicosapentaenoic acid, 20:5(n-3), and docosahexaenoic acid, 22:6(n-3); other major fatty acids were the saturate palmitic acid, 16:0, and the monounsaturate oleic acid, 18:1(n-9). In spite of this general uniformity, univariate and multivariate analysis showed that Caprella acanthifera and C. grandimana differed from the remaining species (C. danilevskii, C. equilibra, C. liparotensis, $C$. penantis, C. santosrosai, Phtisica marina and Pseudoprotella phasma). These two species (C. acanthifera and $C$. grandimana) showed higher concentrations of 18:1(n-7) and 20:4(n-6) and lower percentages of 22:6(n-3). These results, together with higher values of the biomarker ratio $20: 5(n-3) / 22: 6(n-3)$ and a lower ratio 18:1(n-9)/18:1(n-7), suggested a greater contribution of diatoms and macroalgae in the diet of C. acanthifera and C. grandimana and a lesser contribution of flagellates than in the remaining species. The cluster classification of the caprellid specimens from the Strait of Gibraltar based on the fatty acid composition was in agreement with the Cluster output from data of feeding behaviour. Sex-related changes in the fatty acid composition were also explored in C. acanthifera, C. danilevskii and C. penantis; the percentage of 18:0, 20:4(n-6), and 20:5(n-3) was significantly higher in males, whereas 16:1(n-7) was higher in females. The intraspecific differences of fatty acids in different environmental conditions seem to indicate that the consumption of diatoms in contrast to flagellates increases with the degree of eutrophication.
\end{abstract}

Key words: fatty acids, Amphipoda, Caprellidea, Strait of Gibraltar.

RESUMEN: COMPOSICIÓN DE ÁCIDOS GRASOS DE LOS CAPRÉLIDOS (CRUSTACEA: AMPHIPODA) DEL Estrecho DE GibRaltaR. - Se estudió la composición de ácidos grasos de nueve especies de anfípodos caprélidos recolectados en el Estrecho de Gibraltar. Todos los caprélidos se caracterizaron por presentar niveles elevados de ácidos grasos poliinsaturados, principalmente eicosapentaenoico, 20:5(n-3), y docosahexaenoico, 22:6(n-3); otros ácidos grasos importantes fueron el saturado ácido palmítico, 16:0, y el monoinsaturado ácido oleico, 18:1(n-9). A pesar de este patrón general, los análisis univariantes y multivariantes mostraron que, atendiendo a la composición de ácidos grasos, Caprella acanthifera y C. grandimana se diferenciaron significativamente de las especies restantes (C. danilevskii, C. equilibra, C. liparotensis, C. penantis, C. santosrosai, Phtisica marina y Pseudoprotella phasma). Estas dos especies (C. acanthifera y C. grandimana) mostraron porcentajes más altos de 18:1(n-7) y 20:4(n-6) y más bajos de 22:6(n-3). Estos resultados, junto con valores más altos del biomarcador 20:5(n-3)/22:6(n-3) y más bajos del 18:1(n-9)/18:1(n-7) sugieren una mayor contribución de diatomeas y macroalgas en la dieta de $C$. acanthifera y $C$. grandimana y una menor contribución de flagelados. El dendrograma de clasificación de los caprélidos del Estrecho de Gibraltar basado en la composición de ácidos grasos fue similar al obtenido a partir de los datos de comportamiento alimenticio de las especies. Los cambios en la composición de ácidos grasos con respecto al sexo fueron explorados en $C$. acanthifera, $C$. danilevskii y $C$. penantis; el porcentaje de 18:00, 20:4(n-6), y 20:5(n-3) fue significativamente superior en machos, mientras que el de 16:1(n-7) fue superior en las hembras. Las diferencias intraespecíficas en la composición de ácidos grasos en diferentes condiciones ambientales parecen indicar que el consumo de diatomeas frente al de dinoflagelados se incrementa al aumentar el grado de eutrofización.

Palabras clave: ácidos grasos, Amphipoda, Caprellidea, Estrecho de Gibraltar.

*Received October 1, 2003. Accepted April 29, 2004. 


\section{INTRODUCTION}

Caprellidean amphipods are small crustaceans which inhabit many littoral zones. They are common and diverse on erect hydrozoans and bryozoans, and on plant substrata such as macroalgae and seagrasses (McCain, 1968). They feed on suspended materials, prey on other organisms or graze on epibiotic fauna and flora (Caine, 1974). Locally, caprellids are important preys for many coastal fish species (Caine, 1989, 1991) and can be useful as bioindicators of water quality (Guerra-García and García-Gómez, 2001).

The Strait of Gibraltar is an interesting zoogeographical area, especially from the point of view of the interchange of species between the Atlantic and the Mediterranean, and the European and African faunas. Recently, the Marine Biology Laboratory of the University of Seville has been conducting research programmes focusing on taxonomy, ecology and behaviour of the caprellid communities of the Strait of Gibraltar (Guerra-García, 2001a; Guerra-García and García-Gómez, 2001; Guerra-García and Takeuchi, 2002; Guerra-García et al., 2002).

The fatty acid composition of marine amphipods is known to be related to water temperature and feeding modes (Kawashima et al., 1999; Graeve et $a l ., 2001)$ and a fatty acid approach can be useful to explore habitat preferences and feeding strategies. However, there is a lack of studies dealing with the fatty acid composition in the Caprellidea. Data of fatty acids have been recorded only in five caprellid species before this study, all of them collected from Japanese waters (Kawashima et al., 1999): an unidentified caprellid species and four other species
(C. acanthogaster, C. danilevskii, Caprella mutica and $C$. penantis) inhabiting Otsuchi and Mutsu Bays in northern Japan.

The objective of this paper is to analyse the fatty acid composition of various caprellid species from the Strait of Gibraltar and to explore the sex-related changes and the intraspecific variations in fatty acids depending on the environmental conditions. These aspects had not been studied in Caprellidea before this study.

\section{MATERIAL AND METHODS}

\section{Study area}

The Strait of Gibraltar is situated on the border of the Mediterranean Sea and the Atlantic Ocean. Three areas of different environmental characteristics were selected for sampling the caprellids: El Portil and Tarifa island in southern Spain, and Ceuta in north Africa (Fig. 1). El Portil is located in the estuary area of the river Piedras. The place is subject to important fluctuations in salinity and temperature and receives a considerable organic enrichment due to the river influence. Average water temperatures in summer are close to $25^{\circ} \mathrm{C}$ (Guerra-García et al., 2000a). In contrast, Tarifa island, as a part of a Natural Park, is a very well protected area characterised by clean and cooler waters (mean values of about $17^{\circ} \mathrm{C}$ in summer) and highly biodiverse marine benthic communities (Guerra-García and GarcíaGómez, 2000; Guerra-García et al., 2000b). Ceuta is located on the north African side of the Strait of Gibraltar and the water temperature in summer is

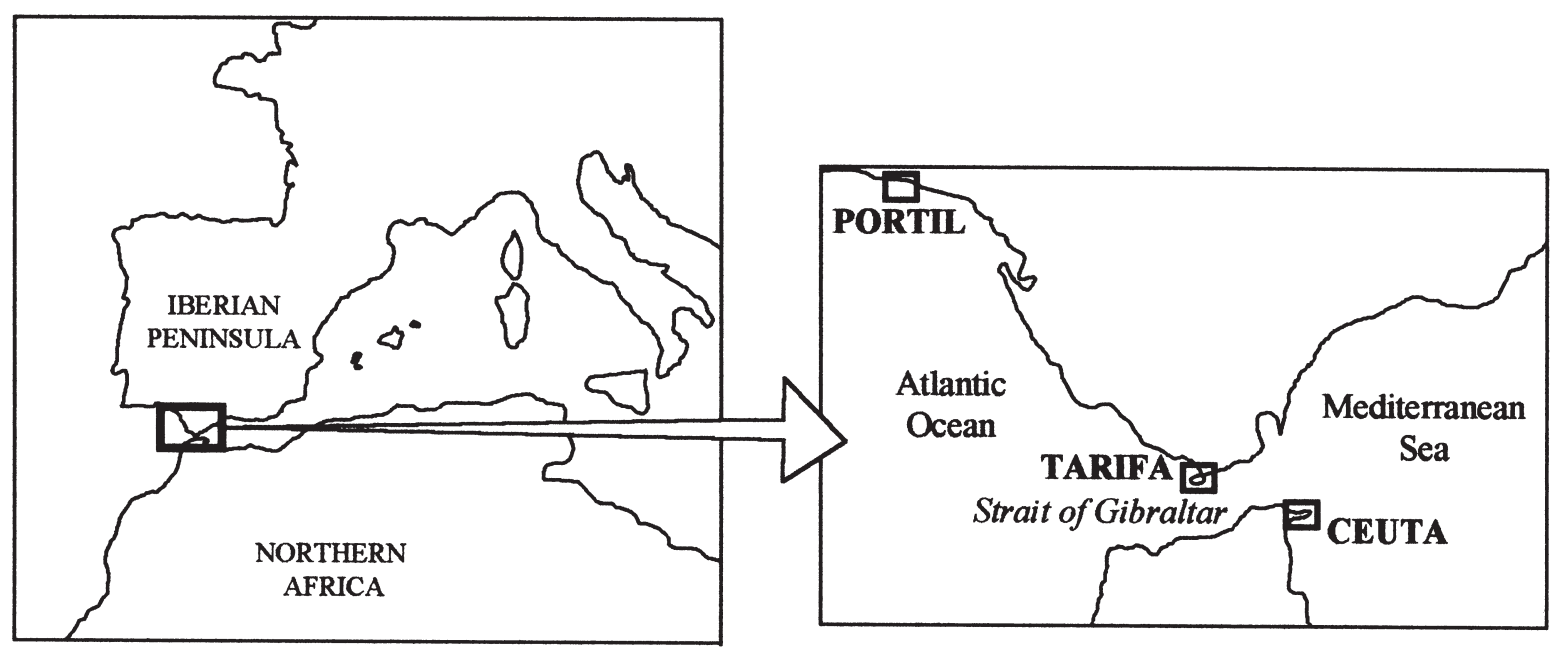

FIG. 1. - Map of the Strait of Gibraltar showing the sampling localities: El Portil, Tarifa and Ceuta. 
Table 1. Caprellids from the Strait of Gibraltar used for the study. Details of locality, data, depth and substrata are given. [n=number of samples; each sample contains a number of specimens enough for chemical analysis (25-30 mg)]

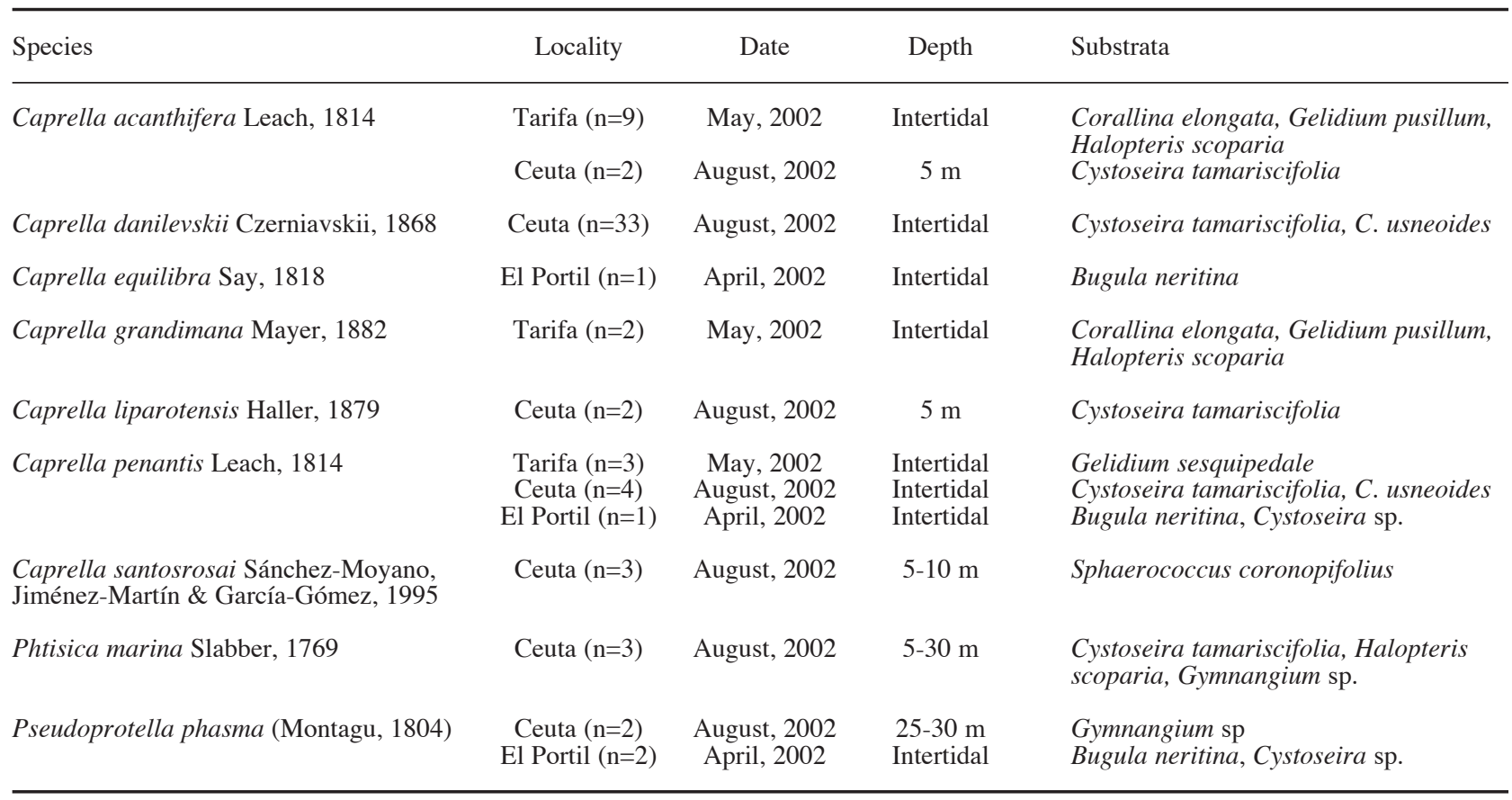

about $19-20^{\circ} \mathrm{C}$ (Guerra-García, 2001b). The degree of human influence in the littoral area of Ceuta is intermediate between the Tarifa island (no anthropogenic influence) and El Portil (a high level of anthropogenic influence). Therefore, in selecting these three areas, a range of conditions is encompassed to check intraspecific variability in the fatty acid composition.

\section{Sample collection}

Nine species of caprellid amphipods were sampled for the study (Table 1). The specimens were collected by hand in intertidal areas and using snorkelling and scuba diving in infralittoral zones. Immediately after sampling, the individuals were sorted into species and stored at $-80{ }^{\circ} \mathrm{C}$ for later analysis.

\section{Fatty acid analysis}

Samples of the different species of caprellids (25-30 mg) were homogenised with $0.9 \% \mathrm{NaCl}$. Fatty acid methyl esters were prepared by a direct transesterification reaction according to Lepage and Roy (1987): $2 \mathrm{ml}$ of methanol-benzene 4:1 (v/v) was added to $0.2 \mathrm{ml}$ of homogenate and then, while stirring, $0.2 \mathrm{ml}$ of acetyl chloride was slowly added. Tubes were tightly closed and maintained at $100^{\circ} \mathrm{C}$ for $1 \mathrm{~h}$. After cooling, $5 \mathrm{ml}$ of $6 \% \mathrm{~K}_{2} \mathrm{CO}_{3}$ solution was added. The tubes were then shaken and centrifuged and an aliquot of the benzene upper phase was injected into the chromatograph for fatty acid analysis.

Analysis of fatty acid methyl esters was performed by gas-liquid chromatography using a Hewlett Packard 5890 gas chromatograph equipped with a $30 \mathrm{~m}$ long $\mathrm{x} 0.25 \mathrm{~mm}$ internal diameter TRWAX fused silica capillary column (Teknokroma, Barcelona, Spain). Peaks were identified by comparison with known standards (Supelco, Bellefonte, PA, USA), and the results were reported as area percentages.

\section{Biomarker ratios}

Based on the fatty-acid composition, a variety of biomarkers and ratios were determined to obtain information on dietary composition, trophic level and feeding behaviour. The total percentage of polyunsaturated (PUFA) and saturated (SFA) were calculated. The ratio 18:1(n-9)/18:1(n-7) has been proposed as a relative measure of carnivorous diet in marine invertebrates (Falk-Petersen et al., 2000; Auel et al., 2002). In addition, the ratios $16: 1(n-7) / 16: 0$ and 20:5(n-3)/22:6(n-3) were assessed, which allows differentiation between a diatom- or flagellate-based diet (Nelson et al., 2001; Auel et al., 2002). 


\section{Statistical analysis}

The possible differences in the fatty acid composition between species, together with the intraspecific differences between sexes and sample sites, were tested. The data was verify for normality using the Kolmogorov-Smirnov test and Levene's test was used to check the homogeneity of variances. Provided that there was not normality and/or homogeneity of variances, the non-parametric Kruskal-Wallis test was used. The affinities between species based on the fatty acid composition were established through Cluster analysis using the UPGMA method (unweighted Pair Group Method using arithmetic Averages) (Sneath and Sokal, 1973). An MDS (nonmetric Multidimensional Scaling) analysis was also conducted and the Kruskal stress coefficient was calculated to test the ordination (Kruskal and Wish, 1978). The Primer computer package v.5 (Clarke and Gorley, 2001) and the program PC-ORD (PCOrdination) v. 3.05 (McCune and Mefford, 1997) were used for multivariate analyses. For univariate analyses the BMDP (BioMedical Data Programs) was used (Dixon, 1983).

\section{RESULTS}

A detailed description of mean values of fatty acid percentages together with the biomarker ratios is given in Table 2 and Figures 2 and 3. At least 29 fatty acids with a number of carbon atoms from 14 to 22 were present in the studied caprellid species. Unsaturated acids were the major fatty acids, accounting for $69-75 \%$ of total fatty acids. Polyunsaturated fatty acids (PUFA) were the dominant unsaturated fatty acids, making up 50\% of the total fatty acids. Eicosapentaenoic acid (20:5(n-3)) and docosahexaenoic acid (22:6(n-3)) were the two major PUFA; other major fatty acids found in all caprellid species were palmitic acid (16:0) and oleic acid (18:1(n-9)).

In general, the fatty acid composition was similar in all species (Table 2). However, the percentage of

TABLE 2. - Percentage of fatty acid composition in the Caprellidea from the Strait of Gibraltar.

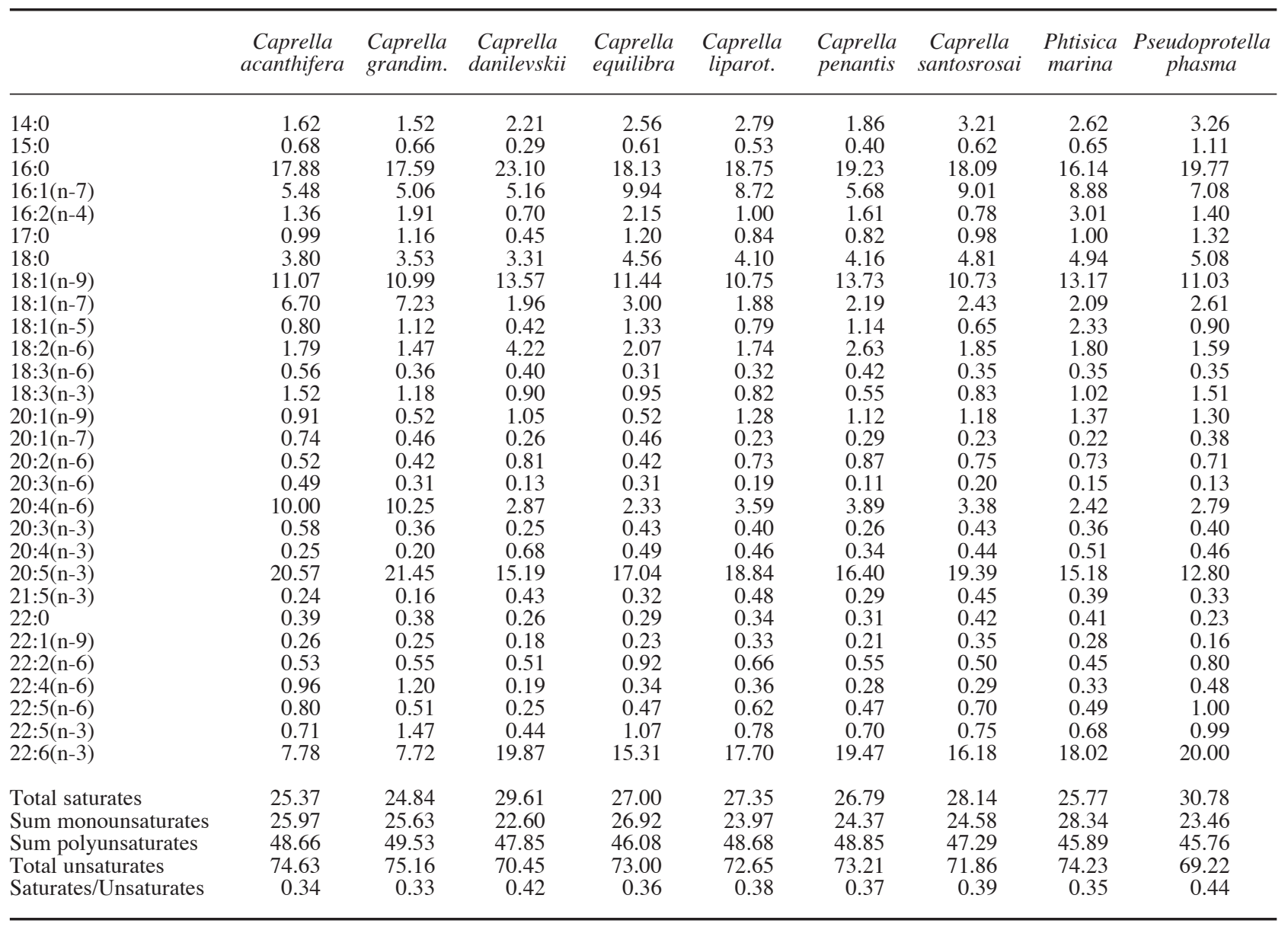



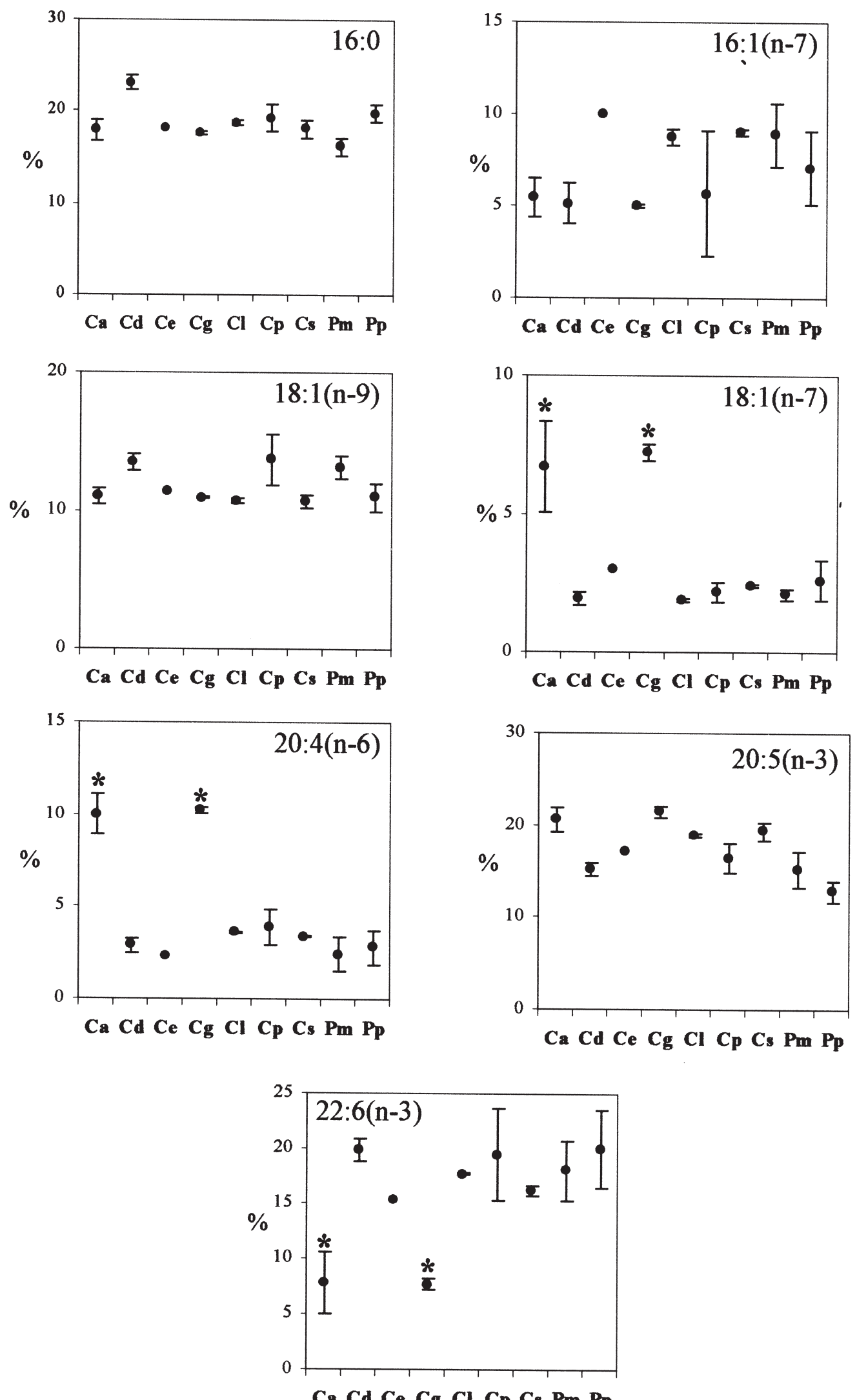

FIG. 2. - Mean values and standard deviations of the percentage of the dominant fatty-acids measured in the studied caprellid species. Ca: Caprella acanthifera; Cd: C. danilevskii; Ce: C. equilibra; Cg: C. grandimana; Cl: C. liparotensis; Cp: C. penantis; Cs: C. santosrosai; Pm: Phtisica marina; Pp: Pseudoprotella phasma. Significant differences were found in C. acanthifera and C. grandimana with respect to the other seven species for 18:1(n-7), 20:4(n-6), 22:6(n-3) $(*, p<0.05)$. 

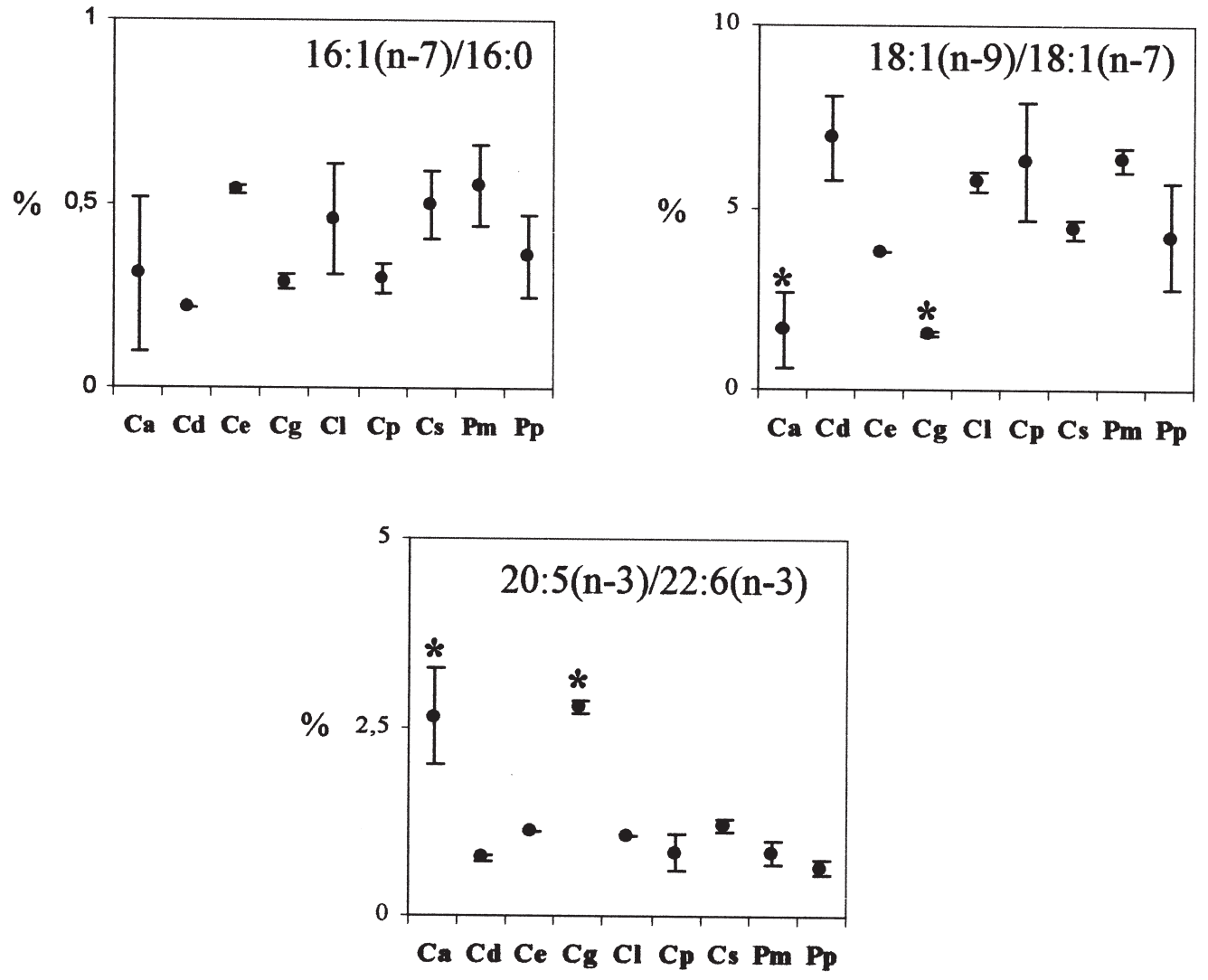

FIG. 3. - Mean values and standard deviations of the biomarker ratios measured in the studied caprellid species. Ca: Caprella acanthifera; Cd: C. danilevskii; Ce: C. equilibra; Cg: C. grandimana; $\mathrm{Cl}$ : C. liparotensis; Cp: C. penantis; Cs: C. santosrosai; Pm: Phtisica marina; Pp: Pseudoprotella phasma. Significant differences were found in $C$. acanthifera and $C$. grandimana with respect to the other seven species for $18: 1(n-9) / 18: 1(n-7)$ and 20:5(n-3)/22:6(n-3) $(*, p<0.05)$.

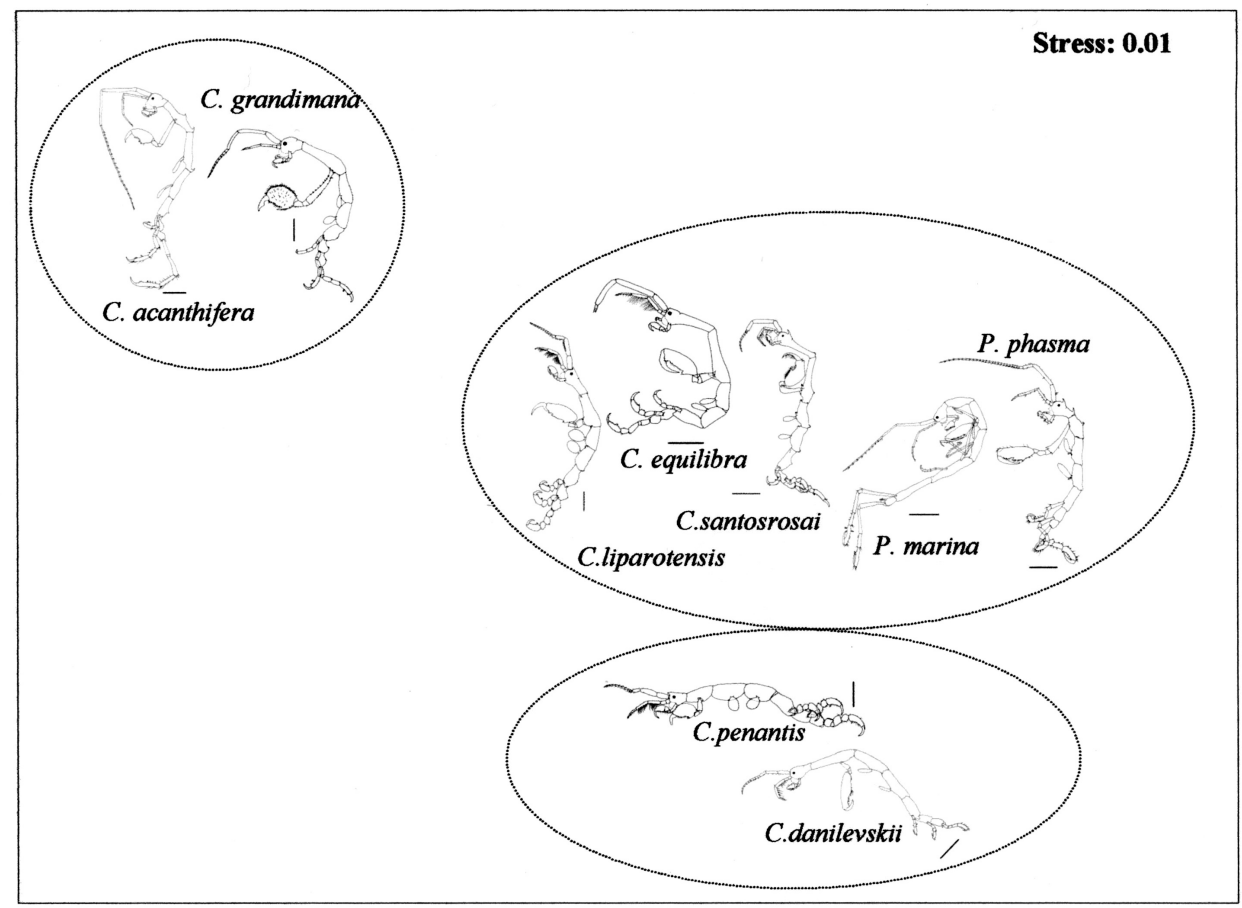

FIG. 4. - MDS ordination of the caprellid species according to the fatty acid composition. Dotted lines circles indicate the groups obtained with the Cluster analysis (Fig. 5). Scale bars: $1 \mathrm{~mm}$. 


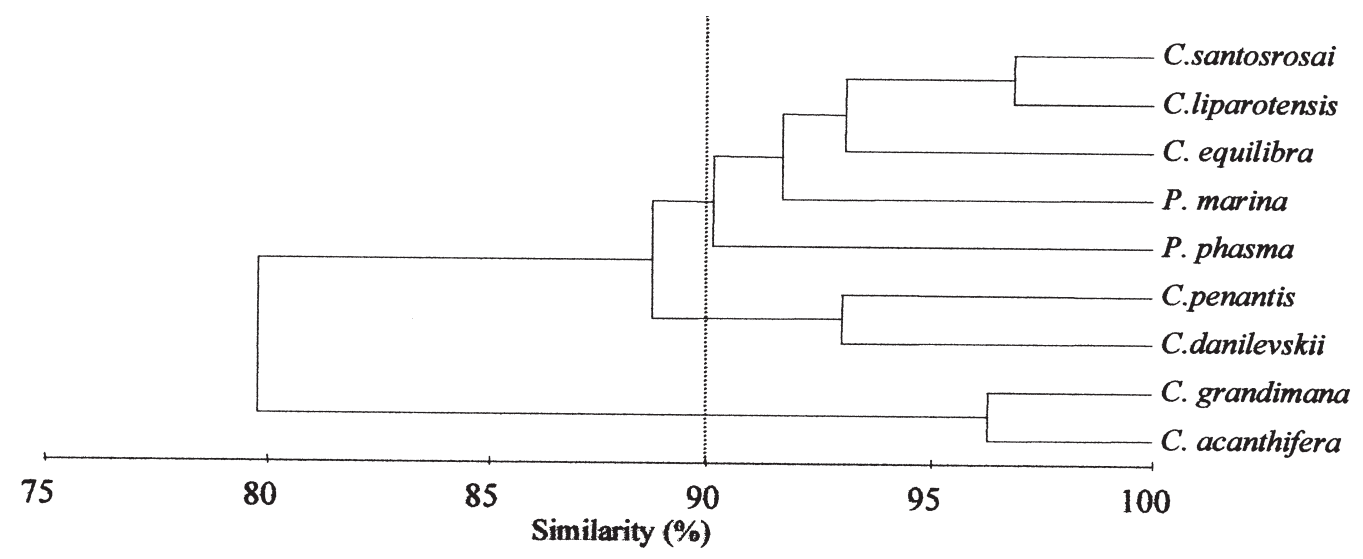

FIG. 5. - Dendrogram of similarity between the caprellid species, produced from percentage data of fatty acids.

the fatty acids $18: 1(\mathrm{n}-7)$ and 20:4(n-6) were significantly higher in $C$. acanthifera and $C$. grandimana than in the remaining species (Kruskal-Wallis test, $\mathrm{p}<0.05)$. Significant differences were also obtained for the percentage of 22:6(n-3), which was lower in C. acanthifera and C. grandimana (Fig. 2).

The biomarker ratio 18:1(n-9)/18:1(n-7) was significantly lower in $C$. acanthifera and $C$. grandi- mana than in other species, whereas the ratio 20:5(n-3)/22:6(n-3) was higher (Kruskal-Wallis test, p<0.05) (Fig. 3)

When the fatty-acid matrix was used in the multivariate analyses to explore the similarity between species, the pattern obtained with the univariate analysis was confirmed (Fig. 4 and 5). Caprella acanthifera and $C$. grandimana were clearly sepa-
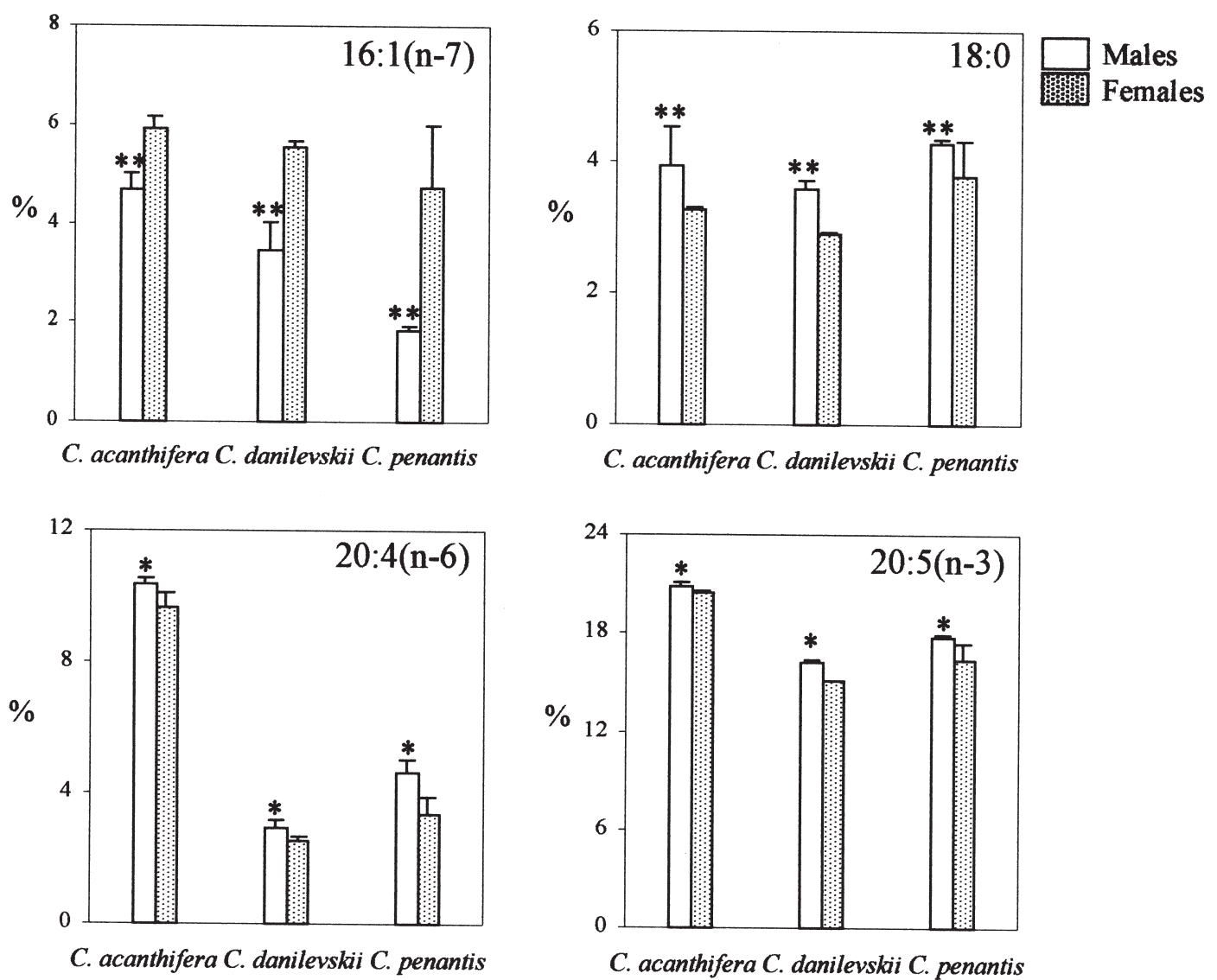

FIG. 6. - Percentage of four selected fatty acids in males and females of Caprella acanthifera, C. danilevskii and C. penantis. The values are expressed as mean and standard deviation (number of pools, $n=3-4$ ). Significant differences in the four fatty acids between males and females were obtained $(* \mathrm{p}<0.05, * * \mathrm{p}<0.01)$. 

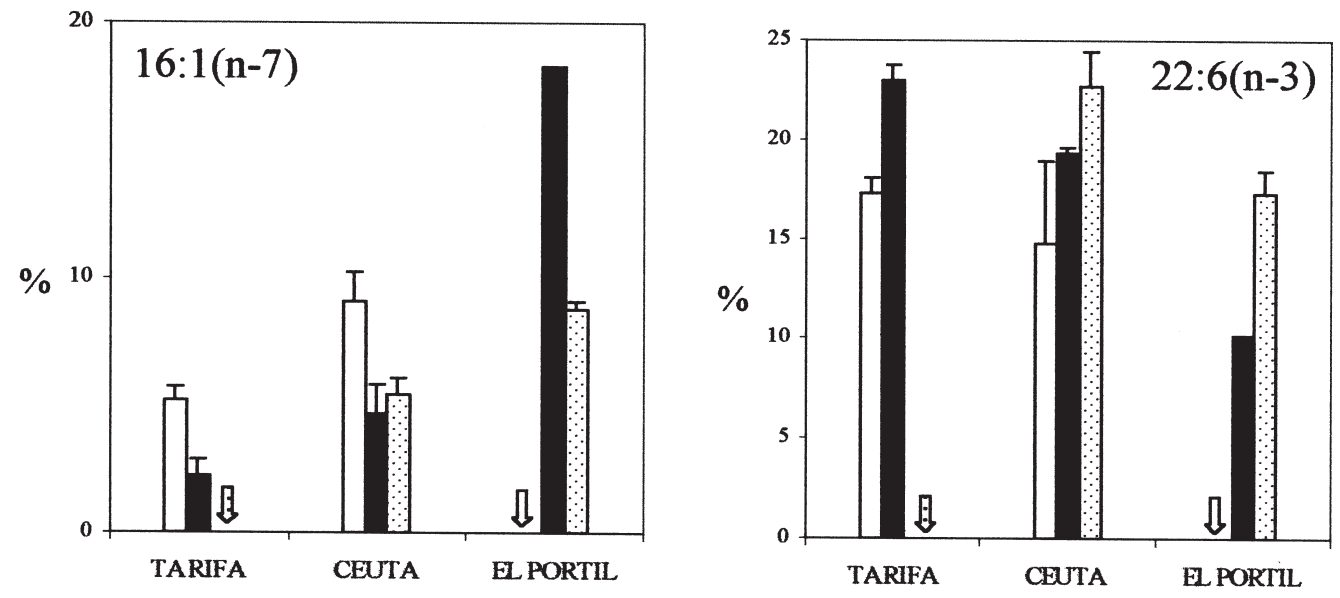

\section{C. acanthifera $\square$ C.penantis $\because$ P.phasma}

FIG. 7. - Comparison of the percentage of 16:1(n-7) and 22:6(n-3) along an increasing gradient of eutrophication from Tarifa (unpolluted area) and El Portil (eutrophic area) in the caprellids Caprella acanthifera, C. penantis and Pseudoprotella phasma. Arrows indicate that the species was not collected from that area. The values are expressed as mean and standard deviation.

rated from the remaining species in both the MDS ordination output (Fig. 4) and the dendrogram (Fig. 5). The Cluster analysis based on the Euclidean distance showed that two species groups can be differentiated (Fig. 5). The first includes $C$. acanthifera and $C$. grandimana, characterised by higher contents of 18:1(n-7) and 20:4(n-6) and lower contents of 22:6(n-3). The second group can be split into two subgroups: the species $C$. penantis and $C$. danilevskii in one subgroup, and $C$. equilibra, $C$. santosrosai, C. liparotensis, Phtisica marina and Pseudoprotella phasma in the other subgroup; the first subgroup was characterised by slightly higher concentrations of $16: 0$ and 18:2(n-6) than the second subgroup.

\section{Sex-related influence on fatty acid composition}

With respect to the intraspecific variation between males and females, data were only available for the species $C$. acanthifera, $C$. danilevskii and $C$. penantis. Significant differences were found for the three species between males and females in the percentage of 16:1(n-7), 18:0, 20:4(n-6) and 20:5(n-3). The amount of $16: 1(\mathrm{n}-7)$ was significantly higher in females whereas the 18:0, 20:4(n-6) and 20:5(n-3) percentages were significantly higher in males (Kruskal-Wallis test, $\mathrm{p}<0.05$ ) (Fig. 6).

\section{Intraspecific variation of fatty acids}

Only the species Caprella penantis was collected in the three study areas (Tarifa, Ceuta, El Portil).
Caprella acanthifera was found in Tarifa and Ceuta but not in El Portil, and Pseudoprotella phasma was collected from Ceuta and El Portil but specimens from Tarifa were not available for this study. There was a common pattern of variation in two of the major fatty acids, 16:1(n-7) and 22:6(n-3), for the three caprellid species (Fig. 7). If we consider a growing gradient of eutrophication from Tarifa to El Portil, an increase in the percentage of 16:1(n-7) and a decrease in 22:6(n-3) could be observed.

\section{DISCUSSION}

In the present study the total fatty acids of the caprellid specimens were analysed. Some previous studies (e.g. Kawashima et al. 1999) differentiated the fatty acids of phospholipids from the fatty acids of triacylglycerols. However, Graeve et al. (2001) showed that the differences between the fatty acid composition of phospholipids as structural components of membranes and triacylglycerols as storage lipids are small. These authors proposed that future studies of benthic amphipods should be done with analysis of the total lipid fatty acid composition.

Four major fatty acids characterised the fatty acid profile of the studied caprellid species, namely 16:0, 18:1(n-9), 20:5(n-3) and 22:6(n-3). These were also the most abundant fatty acids described in various species of the two other amphipods groups, gammarids and hyperids (Clarke et al., 1985; Phleger et al., 2000; Scott et al., 2001; Nelson et al., 2001; Auel et al., 2002; Correia et al. 2003) 
although in some species high levels of 16:1(n-7) (Graeve, 2001) or 20:1(n-9) (Auel, 2002) have also been found.

The fatty acid composition of caprellids has only been previously reported in a study carried out by Kawashima et al. (1999) in northern Japan. Caprellids from the Strait of Gibraltar showed a fatty acid composition similar to that described for the Japanese caprellids, except for 18:1(n-9) and 20:5(n-3), which showed lower values in the species collected in the Strait of Gibraltar. These differences may be related to differences in water temperature, as it has been reported that the amount of 20:5(n-3) increases when water temperature decreases (Kawashima et al., 1999). In the present study the percentage of 20:5(n-3) measured in the caprellid species from Tarifa (characterised by colder waters, $17^{\circ} \mathrm{C}$ in summer) ranged from 18 to $22 \%$, whereas in the species from El Portil (characterised by warmer waters, 25 ${ }^{\circ} \mathrm{C}$ in summer) ranged from 11 to $17 \%$. These ranges seem to support the influence of the temperature on fatty acid composition, although the number of specimens from El Portil is small, so the data must be taken cautiously. In addition to the temperature, the type of diet could also be involved in these variations, as discussed later.

The present study shows that the fatty acid composition of the species Caprella acanthifera and $C$. grandimana differed from that of the other seven species. These two species were characterised by significant higher percentages of 18:1(n-7) and 20:4(n-6) and lower values of 22:6(n-3). These differences were also reflected in some biomarker ratios. Caprella acanthifera and $C$. grandimana showed higher values of the ratio 20:5(n-3)/22:6(n3 ) and lower values of the ratio 18:1(n-9)/18:1(n-7). Among the specific lipid components suggested for use as trophic biomarkers, high levels of the fatty acids 16:1(n-7), 18:1(n-7), 20:5(n-3) are considered to be an indicator of a diatom-based diet (Graeve et al., 2001; Nelson et al., 2001; Auel et al., 2002). In contrast, flagellates usually contain high concentrations of 22:6(n-3) (Sargent et al., 1987; Graeve et al., 1994; Scott et al., 2000), whereas 20:4(n-6) originates from macroalgae and is incorporated unmodified in the lipids of the amphipod (Graeve et $a l ., 2001)$. The fatty acid 18:1(n-9) is considered to be an indicator of a more carnivorous diet (Nelson et $a l ., 2001)$ and has been associated with necrophage species (Graeve et al., 2001). Therefore, the combination of a higher 20:5(n-3)/22:6(n-3) ratio, a lower 18:1(n-9)/18:1(n-7) ratio and higher percentages of 20:4(n-6) suggests that there is a greater contribution of diatoms and macroalgae in the diet of $C$. acanthifera and $C$. grandimana than in that of the remaining species. The fatty acid 20:1(n-9) is also considered to be an indicator of carnivorous dietary input (Hopkins et al., 1993; Virtue et al., 2000; Scott et al., 2001) and in some species of arctic hyperids (Auel et al., 2002) high levels of 20:1(n-9) have been reported. In this study, the percentage of 20:1(n-9) found in the studied caprellids was very low $(0.52-1.05 \%)$, which indicates that the copepod contribution to the diet of these species is very low or inexistent.

The dendrogram obtained in the present study based on the fatty acid composition (Fig. 5) is in agreement with the dendrogram represented by Guerra-García et al. (2002) based on the clinging behaviour associated with feeding strategies. The species $C$.danilevskii and $C$. penantis spend most of their time in a "parallel" posture on the substrate, feeding mainly by scraping, and both species are grouped together in the feeding cluster (Guerra-García et al., 2002). Similarly, Phtisica marina, Pseudoprotella phasma, C. equilibra and C. santosrosai are in the same group because they have a similar feeding behaviour, filtering and predating in an "upright" position. In the fatty-acid cluster output, these species are also very close based on similar percentages of fatty acids. Therefore, it seems that fatty acid composition is significantly related to feeding modes in caprellids.

Although the available data for differentiating the fatty acid composition in males and females are scarce, several clear patterns were obtained for three of the nine studied species. The percentage of 18:0, 20:4(n-6), and 20:5(n-3) was significantly higher in males of the three compared species (C. acanthifera, C. danilevskii and C. penantis), whereas 16:1(n-7) was higher in females. Similar patterns (except for 18:0) have been reported recently for the gammaridean amphipod Gammarus lacusta (Correia et al., 2003). These differences in fatty acid composition could reflect slight differences in feeding strategies, such as the greater consumption of diatoms by the females, maybe due to reproductive purposes. Correia et al. (2003) also found age-related changes in the fatty acid composition in Gammarus lacusta. The percentage of 16:1(n-7) decreased with age, while 18:1(n-9), 20:1(n-9) and 20:1(n-11) increased in adult specimens, although the age-related changes seem to be related to the peroxidation status of the animals in gammarids (Correia et al., 2003). Further 
research in future is encouraged to explain the implications of sex- and age-related changes of fatty acids in caprellidean amphipods.

Similar to the sex-related data, the data of intraspecific variation of the fatty-acid composition in the three studied areas were also limited because only three species could be collected in more than one area; Caprella penantis was found in the three studied areas, C. acanthifera in Tarifa and Ceuta and Pseudoprotella phasma in Ceuta and El Portil. However, an increasing trend of 16:1(n-7) and a decrease in 22:6(n-3) was observed when the level of eutrophication increased from Tarifa to El Portil. This could indicate that the consumption of diatoms in contrast to flagellates increases when the level of eutrophication becomes higher. However the effect of the water temperature could also be involved in the changes in the percentages of these two fatty acids, and it is difficult to separate the influence of the two factors. Future experimental studies should be addressed to further investigating the environmental implications of this intraspecific variation.

\section{REFERENCES}

Auel, H., M. Harjes, R. da Rocha, D. Stübing and W. Hagen. 2002. Lipid biomarkers indicate different ecological niches and trophic relationships of the Arctic hyperiid amphipods Themisto abyssorum and T. libellula. Polar Biol., 25: 374-383.

Caine, E.A. - 1974. Comparative functional morphology of feeding in three species of caprellids (Crustacea, Amphipoda) from the Northwestern Florida Gulf coast. J. Exp. Mar. Biol. Ecol, 15: 81-96.

Caine, E.A. - 1989. Caprellid amphipod behaviour and predatory strikes by fish. J. Exp. Mar. Biol. Ecol, 126: 173-180.

Caine, E.A. - 1991. Caprellid amphipods: fast food for the reproductively active. J. Exp. Mar. Biol. Ecol, 148: 27-33.

Clarke, A., A. Skadsheim and L.J. Holmes. - 1985. Lipid biochemistry and reproductive biology in two species of Gamaridae (Crustacea: Amphipoda). Mar. Biol., 88: 247-263.

Clarke, K.R. and R.N. Gorley. - 2001. Primer (Plymouth Routines In Multivariate Ecological Research) v5: User Manual/Tutorial. PRIMER-E Ltd, Plymouth.

Correia, A.D., M.H. Costa, O.J. Luis and D.R. Livingstone. - 2003. Age-related changes in antioxidant enzyme activities fatty acid composition and lipid peroxidation in whole body Gammarus locusta (Crustacea: Amphipoda). J. Exp. Mar. Biol. Ecol., 289: 83-111.

Dixon, W.J. - 1993. BMDP Statistical Sofware. Univ. California Press. Berkeley.

Falk-Petersen, S., W. Hagen, G. Kattner, A. Clarke and J. Sargent. -2000. Lipids, trophic relationships, and biodiversity in Arctic and Antarctic krill. Can. J. Fish Aquat. Sci., 57: 178-189.

Graeve, M., W. Hagen and G. Kattner. - 1994. Herbivorous or omnivorous? On the significance of lipid compositions as trophic markers in Antarctic copepods. Deep Sea Res., 41: 915-924.

Graeve, M., P. Dauvy and Y. Scailteur. - 2001. Combined lipid, fatty acid and digestive tract content analyses: a penetrating approach to estimate feeding modes of Antarctic amphipods. Polar Biol., 24: 853-862.
Guerra-García, J.M. - 2001a. Habitat use of the Caprellidea from Ceuta, North Africa. Ophelia, 55: 27-38.

Guerra-García, J.M. - 2001b. Análisis integrado de las perturbaciones antropogénicas en sedimentos del Puerto de Ceuta. Efecto sobre las comunidades macrobentónicas e implicaciones ambientales. $\mathrm{PhD}$ thesis, Univ. Sevilla.

Guerra-García, J.M. and J.C. García-Gómez. - 2000. La fauna submarina de la Isla de las Palomas (Tarifa, Cádiz). Temas de Flora, Fauna y Ecología del Campo de Gibraltar, 2: 7-17.

Guerra-García, J.M. and J.C. García-Gómez. - 2001. The spatial distribution of Caprellidea (Crustacea: Amphipoda): a stress bioindicator in Ceuta (North Africa, Gibraltar area). PSZN Mar. Ecol., 22: 357-367.

Guerra-García, J.M. and I. Takeuchi. - 2002. The Caprellidea (Crustacea: Amphipoda) from Ceuta, North Africa, with the description of three species of Caprella, a key to species of Caprella and biogeographical discussion. J. Nat. Hist., 36: 675-713.

Guerra-García, J.M., J. Corzo, I. García-Asencio and J.C. GarcíaGómez. - 2000a. Seasonal fluctuations of Phtisica marina Slabber (Crustacea: Amphipoda: Caprellidea) in an estuarine zone of southwest Spain. Pol. Arch. Hydrobiol., 47: 527-531.

Guerra-García, J.M., J.E. Sánchez-Moyano, J. Corzo, S. MorenoRivas and J.C. García-Gómez. - 2000b. Descripción de las comunidades de algas de la Isla de las Palomas (Tarifa) y de otros enclaves del Sur de España. Almoraima, 23: 189-194.

Guerra-García, J.M., J. Corzo and J. C. García-Gómez. - 2002. Clinging behaviour of the Caprellidea (Amphipoda) from the Strait of Gibraltar. Crustaceana, 75: 41-50

Hopkings, C.C.E, J.R. Sargent and E.M. Nilsen. - 1993. Total lipid content, and lipid and fatty acid composition of the deep-water prawn Pandalus borealis from Balsfjord, northern Norway: growth and feeding relationships. Mar. Ecol. Prog. Ser., 96: 217-228.

Kawashima, H., I. Takeuchi and M. Ohnishi. - 1999. Fatty acid composition in four of caprellid amphipod species (Crustacea) from Otsuchi and Mutsu Bays in Northern Japan. J. Jpn. Oil Chem. Soc., 48:595-599.

Kruskal, J.B. and M. Wish. - 1978. Multidimensional scaling. Sage Publications, Beverly Hills, California.

Lahdes, E., G. Balogh, E. Fodor and T. Farkas. - 2000. Adaptation of composition and biophysical properties of phospholipids to temperature by the crustacean Gammarus spp. Lipids, 35: 1093-1098.

Lepage, G. and C.C. Roy. - 1987. Direct transesterification of all classes of lipids in a one-step reaction. J. Lip. Res., 27: 114-120.

McCaine, J.C. - 1968. The Caprellidea (Crustacea: Amphipoda) from the Western North Atlantic. US Nat. Bull. Mus., 278: 1147.

McCune, B. \& M. J. Mefford. - 1997. PC-ORD. Multivariate analysis of ecological data. Mjm Software Design, Gleneden Beach, USA.

Nelson, M.M., B.D. Mooney, P.D. Nichols and C.F. Phleger. 2001. Lipids of Antarctic Ocean amphipods: food chain interactions and the occurrence of novel biomarkers. Mar. Chem., 73: 53-64.

Phleger, C.F., M.M. Nelson, B. Mooney and P.D. Nichols. -2000. Lipids of Antarctic salps and their commensal hyperiid amphipods. Polar Biol., 23: 329-337.

Sargent, J.R., R.J. Parkes, I. Mueller-Harvey and R.J. Henderson. 1987. Lipid biomarkers in marine ecology. In: M.A. Sleigh (ed.)., Microbes and the Sea, pp. 119-138. Ellis Horwood, Chichester.

Scott, C.L., S. Falk-Petersen, B. Gulliksen, O.J. Lonne and J.R. Sargent. - 2001. Lipid indicators of the diet of the sympagic amphipod Gammarus wilkitzkii in the Marginal Ice Zone and in open waters of Svalbard (Arctic). Polar Biol., 24: 572-576.

Sneath, P.H.A. and R.R. Sokal. - 1973. Numerical taxonomy. Freeman, San Francisco.

Virtue, P., P. Mayzaud, E. Albessard and P. Nichols. - 2000. Use of fatty acids as dietary indicators in northern krill, Meganyctiphanes norvegica, from northeastern Atlantic, Kattegat, and Mediterranean waters. Can. J. Fish. Aquat. Sci., 57: 104-114.

Scient. ed.: A. Sabatés 